\title{
МОДЕЛЮВАННЯ СИСТЕМИ ПРОФЕСІЙНОЇ ПІДГОТОВКИ МАЙБУТНІХ МАГІСТРІВ ПОЧАТКОВОЇ ОСВІТИ ДО ІННОВАЦІЙНОї ДІЯЛЬНОСТІ
}

У статті висвітлено проблему професійної підготовки майбутніх магістрів початкової освіти в закладах вищої освіти. Визначено сутність понять «модель», моделювання». На основі узагальнення наукових розвідок змодельовано та теоретично обгрунтовано систему професійної підготовки майбутніх магістрів початкової освіти до інноваційної діяльності. Представлено три блоки моделі системи: теоретико-методологічний (мета, методологічні підходи та принципи, ідеї зарубіжного досвіду, компоненти профресійної готовності), змістово-процесуальний (зміст, нормативно-правове забезпечення, організаційно-педагогічні умови, форми, методи та засоби навчання) та діагностувально-результативний (кількісні та якісні параметри діагностики: критерії, показники та рівні сфрормованості профресійної готовності, результат). Структурування досліджуваного процесу на блоки є умовним, оскільки складники системи взаємозумовлені, доповнюють один одного і творять цілісний процес професійної підготовки. Взаємодія цих блоків у системі професійної підготовки забезпечить постійний цілеспрямований і послідовний вплив на їі ефективність через поєднання взаємопов'язаних складників.

Доцільно зазначити, що під час моделювання системи професійної підготовки визначальними були системний підхід у поєднанні із синергетичним з його відкритістю, доступністю і багатоваріантністю, а також діяльнісний, відповідно до якого формування професійної готовності відбувається у різних видах діяльності.

Доведено, що представлена модель системи дає змогу розглядати профресійну підготовку як цілісний процес, що сприяє підвищенню рівня профресійної готовності майбутніх магістрів початкової освіти до інноваційної діяльності, а також дає змогу зрозуміти характер взаємозалежності між ії структурними компонентами, виявити характерні особливості зазначеного процесу, за необхіднсті, здійснити корекцію окремих компонентів із метою оптимального досягнення поставленої мети. Цінність і цілісність моделі системи забезпечуються єдністю їі структурних компонентів; точністю і повнотою системних характеристик; чіткістю і лаконічністю з достатнім ступенем деталізації; легкістю і доступністю у використанні.

Ключові слова: моделювання, система, профресійна підготовка, інноваційна діяльність, майбутні магістри початкової освіти.

Постановка проблеми. Сучасні реалії, орієнтація українського суспільства на демократичні принципи, реорганізація системи вищої освіти зумовлюють необхідність моделювання нової системи професійної підготовки фахівців до інноваційної діяльності. Професійну підготовку майбутніх магістрів початкової освіти до інноваційної діяльності розуміємо як систему організаційно-педагогічних умов, відповідного освітнього середовища та наявності навчально-методичного забезпечення, спрямованих на фрормування професійної готовності магістрантів до інноваційної діяльності.

Розглядаючи професійну підготовку майбутніх магістрів початкової освіти до інноваційної діяльності з позицій системного та синергетичного підходів, ми дійшли висновку, що однією з найважливіших якостей освітнього процесу ЗВО є його цілісність. Тому систему професійної підготовки спробуємо подати в наочній змодельованій формі, яка дає змогу показати цілісну структуру та взаємозв'язок усіх компонентів (Рис. 1).

Аналіз останніх досліджень і публікацій. У науковій літературі описано різні системи підготовки вчителів, зокрема таких авторів, як: А. Гедзика (система підготовки майбутнього вчителя технологій до викладання курсу креслення в загальноосвітніх навчальних закладах); М. Жалдака (система підготовки вчителя до використання інформаційнокомунікаційних технологій у навчальному процесі); В. Лабунця (методична система інструментально-виконавської підготовки майбутнього вчителя музики); О. Ліннік (система підготовки майбутнього вчителя до організації суб'єкт-суб'єктної взаємодії з учнями початкової школи); Л. Михайленко (система методичної підготовки вчителя математики у вищому навчальному закладі за заочною формою навчання); О. Спіріна (методична система 
базової підготовки вчителя інформатики за кредитно-модульною технологією); І. Ткаченко (система методичної підготовки майбутнього вчителя астрономії); О. Шапрана (система інноваційної підготовки майбутнього вчителя в умовах навчально-науково-педагогічних комплексів) та інші. Різнотипні моделі у професійній підготовці майбутніх фахівців досліджували А. Алексюк, С. Батишев, С. Гончаренко, Р. Гуревич, О. Дубасенюк, І. Зязюн, Н. Ничкало, Л. Лук'янова та інші. Проте з-поміж них немає цілісної системи професійної підготовки майбутніх магістрів початкової освіти до інноваційної діяльності. Доцільно зазначити, що моделювання освітніх систем $є$ відносно новим методом дослідження в педагогічній науці.

Мета статті полягає у моделюванні та теоретичному обґрунтуванні системи професійної підготовки майбутніх магістрів початкової освіти до інноваційної діяльності.

Виклад основного матеріалу. Вибір моделювання як методу дослідження пояснюється тим, що модель дає змогу зрозуміти характер взаємозалежності між структурно-фрункціональними елементами (компонентами), а також синтезувати й виявити характерні особливості досліджуваного процесу. Ми спиралися на те, що моделювання пов'язане з теоретичним пізнанням. Об'єктом теоретичного знання $€$ аналіз сутності пізнаваного, під час якого ідеалізовано виокремлюється найбільш суттєве, що потім об'єктивується, моделюється у вигляді матеріальних конструктів за допомогою знаково-символічних засобів. Спроєктована модель віддзеркалює знання про те, що повинно бути сорормоване. Модель - це розроблений на основі теорії варіант практичної діяльності (€. Ямбург), що є певною системою.

У науковій літературі поняття «модель» постійно трансформується, набуваючи нових значень. Наприклад, науковець П. Дзюба стверджує, що модель - внутрішня структурна організація оригіналу, яка імітує спосіб взаємодії об'єкта із середовищем. Встановлюючи подібність моделі й оригіналу за частинами їхніх структур, ми отримуємо інформацію про функції моделі, спираючись на фрункції оригіналу [4, с. $1-8]$.

Варте уваги твердження дослідниці С. Сисоєвої про те, що модель, яка є інструментом пізнання, засобом інтерпретації та пояснення явищ реальності, здатна замінювати об'єкт-оригінал на певних етапах процесу [6, с. 118].

Погоджуємося 3 думкою науковців М. Артюшина, О. Клименко та Г. Михайлюк, які вважають, що запровадження інноваційного навчання у вищій освіті потребує розроблення та впровадження національної інноваційної, принципово іншої моделі організації освітнього процесу, ключовою відмінністю та сучасним стратегічним пріоритетом якої має бути цільова зорієнтованість на підготовку майбутнього фрахівця до життя в умовах сучасного, динамічного суспільства, що забезпечує його становлення як активного суб'єкта змін та інновацій, здатного до самостійної ініціації та реалізації інноваційної діяльності [1, С. 15-22, 5, С. 58-63].

Метод моделювання забезпечує вибір оптимальних способів вирішення проблеми, передає динаміку розвитку визначених властивостей, передбачає зміну способів педагогічного впливу відповідно до зміни об'єкта навчання, дає змогу аналізувати не лише перебіг навчально-виховного процесу, його розвиток, а й умови, у яких він відбувається [3, с. 490-491].

Моделювати означає створювати зразки нових освітніх систем і процесів, на основі яких можна пізнавати складні явища та долати негативні виклики. Проте слід пам'ятати, що жодна модель не дає вичерпного уявлення про досліджувану систему, не дає змоги повністю передбачити та описати траєкторію її розвитку. Тому під час конструювання моделі доводиться знаходити компроміс між її складністю, кількістю включених елементів і рівнем валідності.

За переконанням ученого В. Бикова, «моделювання системи дає змогу виявити причиннонаслідкові зв'язки й уточнити чинники, прогнозувати наслідки впровадження інновацій, оцінити користь і можливі недоліки, підвищити продуктивність роботи науково-педагогічних працівників 3ВО» [2, с. 292]. Крім того, моделювання дає змогу цілісно розглядати професійну підготовку через компетентнісний підхід - від постановки мети до отримання результатів.

Метою моделювання системи в контексті нашого дослідження був вибір найкращого варіанта її майбутнього еталонного стану, який міг би забезпечити високий рівень сформованості професійної готовності майбутніх магістрів початкової освіти до інноваційної діяльності. Головний принцип проєктування такої моделі системи - віддзеркалення в ній кращого вітчизняного і зарубіжного досвіду, власного педагогічного досвіду та підпорядкування його змістових характеристик стратегічним цілям забезпечення результативності та якості профресійної підготовки майбутніх фахівців спеціальності 013 «Початкова освіта» OP «Магістр». На нашу думку, у моделі, що інтегрує функціонування різних складників системи підготовки магістрантів, важливо показати структуру та ступінь взаємозв'язку всіх аспектів освітнього процесу 3ВО. Тому вважаємо, що одним із завдань моделювання системи професійної підготовки $€$ визначення цілей і конкретних завдань цього процесу. Моделювання системи передбачало аналіз, діагностику, прогнозування. Основою слугували наукові підходи, принципи професійної підготовки майбутніх магістрів початкової освіти, 


\section{ТЕОРЕТИКО-МЕТОДОЛОГІЧНИЙ БЛОК}

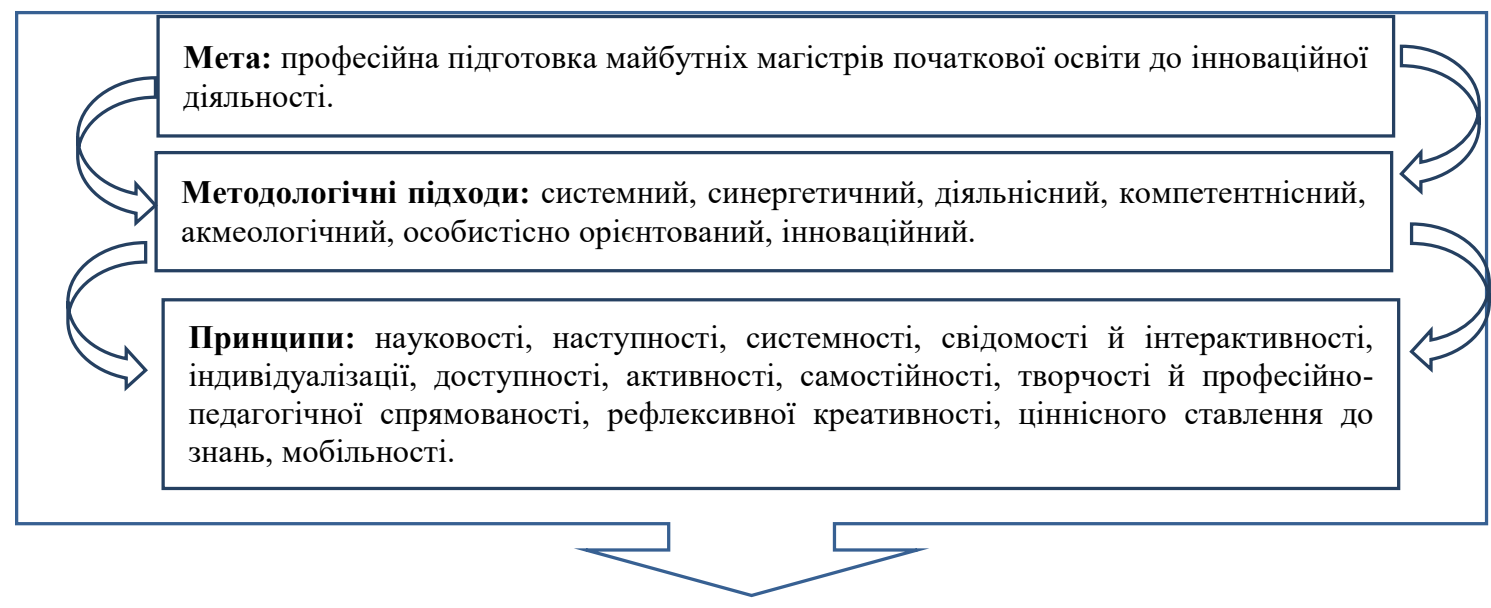

ЗМІСТОВО-ПРОЦЕСУАЛЬНИЙ БЛОК

\begin{tabular}{|c|}
\hline Освітнс середовище \\
закладу вищої освіти
\end{tabular}

Організаційно-педагогічні умови:

- інтеграція інноваційної діяльності;

- наявність матеріально-технічної бази;

- формування мотивації до інноваційної діяльності;

- оновлення та систематизація змісту професійної підготовки;

- реалізація форм і методів організації професійної підготовки до інноваційної діяльності.
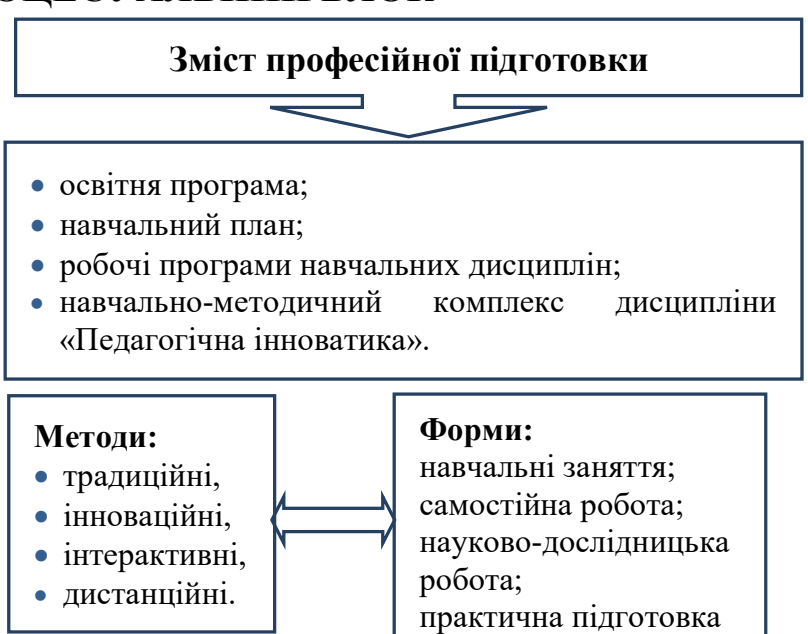

\section{Форми:}

навчальні заняття; самостійна робота; науково-дослідницька робота; практична підготовка контрольні заходи.

Компоненти професійної готовності

\section{ДІАГНОСТУВАЛЬНО-РЕЗУЛЬТАТИВНИЙ БЛОК}

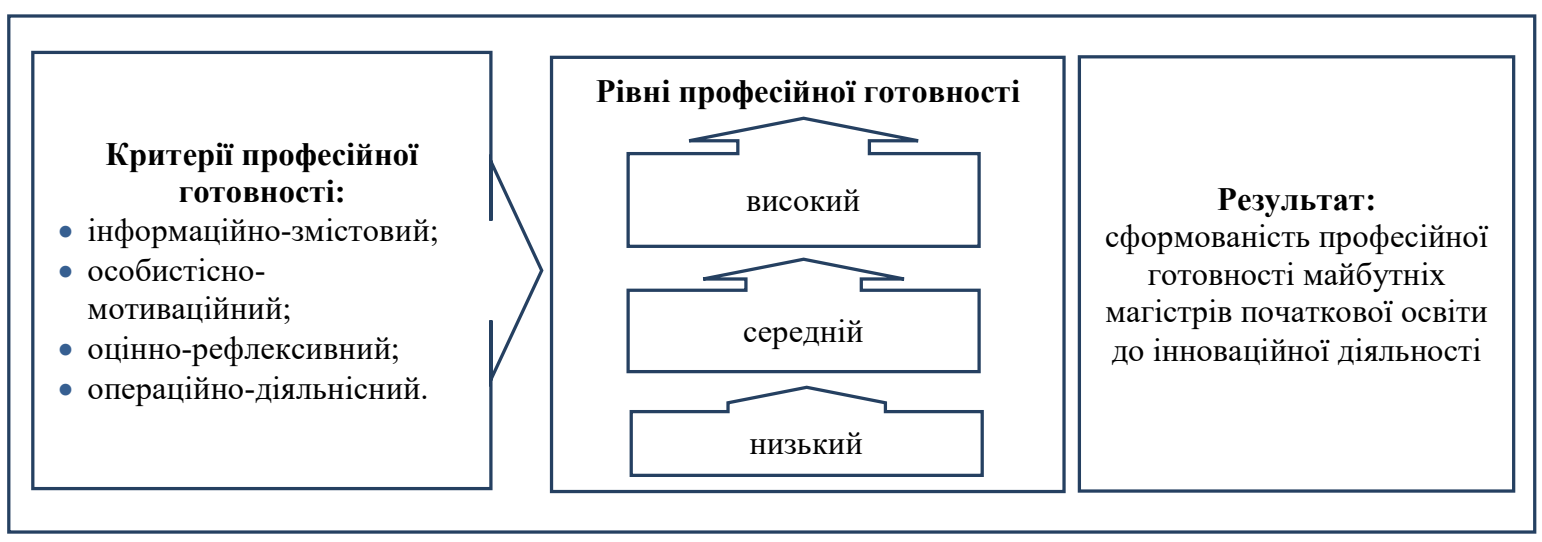

Рис. 1. Модель системи професійної підготовки майбутніх магістрів початкової освіти до інноваційної діяльності 
розроблені на рівні теоретичних і логічних висновків; дані, одержані в результаті досліджень, проведених у ЗВО.

Розглядаючи професійну підготовку майбутніх магістрів початкової освіти до інноваційної діяльності з позицій системного та синергетичного підходів, ми дійшли висновку, що однією з найважливіших якостей освітнього процесу 3ВО є його цілісність. Тому систему професійної підготовки спробуємо подати в наочній змодельованій формі, яка дає змогу зобразити цілісну структуру та взаємозв'язок усіх компонентів (Рис. 1).

Модель системи ґрунтується на чіткому визначенні мети - профресійна підготовка майбутніх магістрів початкової освіти до інноваційноі діяльності. Чітке бачення мети важливе, оскільки мета $є$ тим орієнтиром, який уможливить визначення всіх наступних складових компонентів змодельованої системи, кожен з яких сприяє досягненню поставленої мети та виробленню практичних рекомендацій щодо її вдосконалення.

На основі узагальнення науково-практичного досвіду моделювання систем професійної підготовки нами визначено основні три блоки моделі системи: теоретико-методологічний (мета, методологічні підходи та принципи, ідеї зарубіжного досвіду, компоненти професійної підготовки), змістово-процесуальний (зміст, нормативноправове забезпечення, організаційно-педагогічні умови, форми, методи та засоби навчання) та діагностувально-результативний (кількісні і якісні параметри діагностики: критерії, показники та рівні сформованості професійної готовності, результат). Структурування досліджуваного процесу на блоки є умовним, оскільки складники системи взаємозумовлені, доповнюють один одного і творять цілісний процес професійної підготовки. Взаємодія цих блоків у системі професійної підготовки забезпечить постійний цілеспрямований і послідовний вплив на її ефективність через поєднання взаємопов'язаних складників. Зауважимо, що під час моделювання системи ми спиралися на загальну структуру професійної готовності магістрантів до інноваційної діяльності, яка включає такі компоненти: когнітивний, мотиваційний, рефрлексивний, праксеологічний.

Доцільно зазначити, що під час моделювання системи професійної підготовки визначальними були системний підхід у поєднанні з синергетичним з його відкритістю, доступністю і багатоваріантністю, а також діяльнісний, відповідно до якого формування професійної готовності відбувається у різних видах діяльності. Проаналізуємо основні блоки моделі.

Теоретико-методологічний блок становить методологічне підґрунтя професійної підготовки майбутніх магістрів початкової освіти до інноваційної діяльності і представлений комплексом методологічних підходів (системний, синерге- тичний, діяльнісний, компетентнісний, акмеологічний, особистісно орієнтований, інноваційний) та принципів (принципи науковості, системності, доступності, цілісності, наступності, неперервності, свідомості й інтерактивності, наочності, індивідуалізації, активності, самостійності, творчості й професійно-педагогічної спрямованості, креативності, ціннісного ставлення до знань, інтеграції, мобільності). Цей блок також презентує основні компоненти професійної готовності майбутніх магістрів початкової освіти до інноваційної діяльності (когнітивний, мотиваційний, рефлексивний, праксеологічний).

Змістово-процесуальний блок моделі системи професійної підготовки розкриває організаційно-педагогічні умови вдосконалення цієї системи, зміст, форми, методи та засоби професійної підготовки магістрантів у ЗВО. Наукове обґрунтування змісту професійної підготовки магістрантів до інноваційної діяльності охоплює такі етапи: теоретико-методологічне обґрунтування основних дефініцій процесу формування професійної готовності до інноваційної діяльності; розроблення навчально-методичного забезпечення та включення його у зміст професійної підготовки магістрантів.

Діагностувально-результативний блок включає діагностику сформованості професійної готовності майбутніх магістрів початкової освіти до інноваційної діяльності як результату професійної підготовки. Він передбачає розроблення критеріїв сформованості професійної готовності; визначення їхніх рівнів і показників; використання методик оцінки кожного показника (інструментарій оцінки); аналіз оцінки досягнень. Визначення рівнів (високий, середній, низький) і показників сфрормованості за кожним компонентом (когнітивний, мотиваційний, рефлексивний, праксеологічний) передбачає розроблення системи діагностичного забезпечення, яка включає анкетування, тестування, спостереження, методики вивчення та аналіз результатів, порівняння та кореляцію отриманих результатів. Зв'язок кореляції та вдосконалення полягає в тому, що отриманий під час формування професійної готовності результат співвідноситься з поставленою метою та за необхідності визначає корекцію всіх попередніх блоків.

Отже, теоретично обґрунтована модель системи професійної підготовки майбутніх магістрів початкової освіти до інноваційної діяльності дає змогу зрозуміти характер взаємозалежності між її структурними компонентами, виявити характерні особливості зазначеного процесу, за необхідності здійснити корекцію окремих компонентів із метою оптимального досягнення поставленої мети.

Висновки і пропозиції. Отже, можемо зробити висновок, що спроєктована модель має системний характер, що забезпечується взаємозв'язком і взаємозумовленістю ії компонентів 
(теоретико-методологічного, змістово-процесуального та діагностувально-результативного блоків). Окрім того, слід зазначити, що у моделюванні системи значну роль відіграє особистість викладача та здобувача вищої освіти, їхнє уміння вибудувати суб'єкт-суб'єктну взаємодію на особистісно орієнтованому та діяльнісному підходах, на яких, по суті, будується весь освітній процес у ЗВО. Цінність і цілісність моделі системи забезпечується єдністю їі структурних компонентів; точністю і повнотою системних характеристик; чіткістю і лаконічністю з достатнім ступенем деталізації; легкістю і доступністю у використанні.

\section{Список використаної літератури:}

1. Артюшина М. Сутність та особливості інноваційно-зорієнтованого підходу у сучасній вищій освіті. Збірник наукових праць Уманського державного педагогічного університету імені Павла Тичини. Умань : Уманський державний педагогічний університет імені Павла Тичини, 2009. 4. 3. С. $15-22$.
2. Биков В. Моделі організаційних систем відкритої освіти : монографія. Київ : Атака, 2008. $684 \mathrm{c}$.

3. Гончаренко С. Методи дослідження в педагогіці. Енциклопедія освіти / Акад. пед. наук України, гол. ред. В. Кремень. Київ : Юрінком Інтер, 2008. С. 490-491.

4. Дзюба П. Теоретична модель професійного становлення майбутніх офріцерів-прикордонників на основі особистісно орієнтованого навчання. Педагогічні науки: Вісник Національної академії державної прикордонної служби України. 2010. № 2. С. 1-8.

5. Клименко О., Михайлюк Г. Болонський процес в Україні: в пошуку національної моделі системи вищої освіти. Наукові записки Інституту законодавства Верховної Ради України : зб. наук. пр. Київ : ІЗВРУ, 2013. № 3. С. 58-63.

6. Сисоєва С., Соколова І. Проблеми неперервної професійної освіти: тезаурус наукового дослідження. Київ : Видавничий дім «ЕКМО», 2010. 362 c.

Tsiuniak O. Professional training system modeling of future masters of elementary education for innovation activity

The problem with the professional training of future masters of elementary education in higher education institutions is highlighted in the article. The essence of such concepts as "model", "modeling", "system" is defined. Based on the generalization of research studies, the professional training system of future masters of elementary education for innovation activities is modeled and theoretically substantiated. Three following blocks of the system model are presented: theoretical and methodological (purpose, scientific approaches and principles, concepts of international practices, elements of professional readiness), content-procedural (content, regulatory support, organizational and pedagogical conditions, forms, methods and teaching techniques) and diagnostic and effective (quantitative and qualitative parameters of diagnosis: criteria, indicators and levels of professional readiness, results). The structuring of the studied process into blocks is relative, because the system components are interdependent. They complement one another and create a holistic training process. The interaction of these blocks in the training system will provide a constant, purposeful and consistent impact on its effectiveness through a combination of interrelated components.

It should be noted that the system and activity approaches have been a guiding principles during the training system modeling, because the system approach in combination with the synergetic approach sets with its openness, accessibility and diversity, and professional readiness is formed in different activities during the activity approach.

It is proved that the presented model of the system allows us to consider professional training as a holistic process, which helps to increase the professional readiness level of future masters of elementary education for innovation activity. It also allows to understand the nature of the interdependence between its structural components, to identify the process characteristics, and if necessary, to correct the individual components to achieve the goal. The value and integrity of the system model are ensured by the unity of its structural components; accuracy and completeness of system characteristics; clarity and conciseness with a sufficient degree of detail; ease and affordability.

Key words: model, professional training, innovative cooking, future masters of elementary education. 